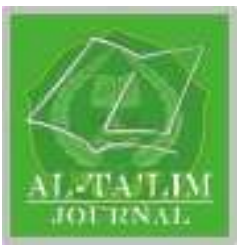

AL-TA'LIM JOURNAL, 24 (2), 2017, (93-102)

(Print ISSN 1410-7546 Online ISSN 2355-7893)

Available online at http://journal.tarbiyahiainib.ac.id/index.php/attalim

\title{
The Effect of Problem Based Learning on EFL Students' Critical Thinking Skill and Learning Outcome
}

Received: $07^{\text {th }}$ March 2017; Revised:18 ${ }^{\text {th }}$ April 2017; Accepted: $25^{\text {th }}$ July 2017

Permalink/DOI: http://dx.doi.org/10.15548/jt.v24i2.271

\section{Abdul Bashith*)}

Universitas Islam Negeri Maulana Malik Ibrahim Malang, Indonesia.

E-mail: abbash98@yahoo.co.id

\section{Saiful Amin}

Universitas Islam Negeri Maulana Malik Ibrahim Malang, Indonesia.

E-mail: samin.geo87@gmail.com

*) Corresponding Author

\begin{abstract}
This research aims to examine the effect of Problem Based Learning (PBL) model to students' critical thinking skill and learning outcome. It was conducted on the $11^{\text {th }}$ graders of social science program at SMAN 6 Malang. The research material was the problems of demography. Research method was quasi experiment with non equivalent control group design. The data analysis used t-test technique. The research result showed that PBL learning model affected students' critical thinking skill and learning outcome in SMAN 6 Malang. The average gain score of experimental class is 33.10, higher than control class, which is 16.24 . The result of t-test analysis is 0.000 smaller than the significance of 0.05 . It is suggested that PBL becomes one of aalternative teaching models that could be implemented to enhance students critical thingking skill.
\end{abstract}

Keywords: Problem based learning; critical thinking skill; learning outcome

How to Cite: Bashith, A., \& Amin, S. (2017). The effect of problem based learning on EFL students' critical thinking skill and learning outcome. Al-Ta Lim Journal, 24 (2). doi:http://dx.doi.org/10.15548/jt.v24i2.271

\section{INTRODUCTION}

Problem Based Learning (PBL) was first applied by Howard Barrows in 1969 (Gunantara, Suarjana, \& Riastini, 2014; Muhson, 2009; Paloloang, 2014; Rusnayati \& Prima, 2011; Sadia, 2007; Savin-Baden \& Major, 2004; Setyorini, Sukiswo, \& Subali, 2011; Suci, 2008). It was applied to the medical school at McMaster University School of Medicine, Canada. At that time, PBL models was applied to solve the problems in the health sector. Furthermore, it was adopted in the school to improve learning outcomes.

PBL is a learning model using authentic problems as a context for students in solving problem and thinking critically in order to get the knowledge and to learn making decisions. The authentic problems become a starting point on PBL learning, so they will encourage the students to collect information and data to solve problems.

Barrows (1996) described that the characteristics of PBL are: (1) problem-based, learners must deal with a real life (authentic) problem that they might encounter outside of the learning environment. (2) Problemsolving, learners apply problem-solving skills required in their careers to this learning process. (3) Student-centered, learners assume responsibility for their own learning. (4) Selfdirected learning, learners develop research skills because they are required to gather current information in order to complete the problem-solving process. (5) Reflection, learners, through group discussions, reflect on what was learned concerning the problem, its 
essential elements, how it relates to previously encountered problems, which in turn enhance the transfer of knowledge to use with future problems (Barrows, 1996; Dochy, Segers, Van den Bossche, \& Gijbels, 2003; Savery, 2015; Savery \& Duffy, 1995).

The stages of PBL learning model consist of: (1) to orient students to the problem; (2) to organize students for their study; (3) to assist independent group investigation; (4) to develop and present artifacts and exhibits; and (5) to analyze and evaluate the problem-solving process (Anwar, 2017; De Graaf \& Kolmos, 2003; HmeloSilver, 2004; Mills, Treagust, \& others, 2003). The implementation of PBL learning stage above is done in groups. Mentoring teachers at this stage are important in order to make the learning in accordance with the plan.

The application of PBL learning model in this study is based on its benefit in increasing the critical thinking skill. Subramaniam described that PBL introduced by Howard Barrows, is an ideal model to develop critical thinking skill (Anwar, 2017; Romauli, Rahayu, Suhoyo, Dibyasakti, \& Mustikarachmi, 2009; Srinivasan, Wilkes, Stevenson, Nguyen, \& Slavin, 2007; Tandogan \& Orhan, 2007). Students can bring out their critical thinking skill to solve problems. According to (Kronberg \& Griffin, 2000)) some applicable learnings to practice critical thinking skills include problem analysis, problem solving or problem-based learning that emphasizes the methods of science, cooperative methods and scientific inquiry.

Hadi (2013) in his research described that PBL strategies influence the critical thinking skills and learning outcomes of the Biology students in senior high school in Malang. The result is in accordance with (Kurniawati, 2016) that the model PBL can improve science students' critical thinking in fourth grade elementary school. Based on the above researches, it does not only brings positive influence on critical thinking skills, but also improves students' learning outcomes.

The influence of PBL learning model on students' learning outcomes is supported by (Koestiningsih, 2011) who states that there are significant differences between the results of the class X, SMK 1 Blitar that learns physics using PBL and that with the conventional model. The result of study on a group of PBL is better than the conventional group. In addition, (Lestari, 2011) suggests that the science learning outcomes of VIII grade students of SMPN 2 Blitar who learn using Problem Based Learning is higher than that of the students who learn conventionally.

Wulandari \& Surjono (2013) state that there are significant differences in learning outcomes among students taught by PBL method and the students taught by demonstration learning method. The outcomes of students taught by PBL method is higher than that of the students taught by demonstration method. The results of the previous studies are used in this study as the theoretical foundation for the application of the PBL model in geography teaching at SMAN 6 Malang.

PBL is suitable to apply in the teaching of geography since it studies geosphere phenomena that occur in everyday life. These phenomena requires critical thinking skills, for example in the matter of population (Anthroposphere). The material discussed population problems both quantitatively and qualitatively. To understand the problems, it requires contextual learning. In addition, it requires critical thinking to solve them.

\section{METHOD}

This research is a quantitative study using a quasi-experiment models with nonequivalent control group design. Instruments in this study employs an essay test based on indicators of learning. The critical thinking skills data are from the test scores of each class. The data is categorized based on the critical thinking skills criteria. Learning 
outcomes data are obtained from the pre_test and Posttest scores. The calculation result are from the reduction of the scores of Posttest and pre_test in the form of gain score used to test the hypothesis.

Then, the researcher compares the percentage of critical thinking skills data of both groups. The learning outcomes data are analyzed by T-test using SPSS program version 16.0 for Windows with $5 \%$ significance level. The taken Decision is based on hypothesis testing. Hypothesis testing is a step or procedure to determine whether the hypothesis is accepted or rejected. The data used to test the hypothesis is gain scores of learning outcome data. Testing the hypothesis in this study are as follows.

1. $\mathrm{H}_{0}$ : PBL learning model does not affected on improvement of learning outcomes.

2. $\mathrm{H}_{1}$ : PBL learning model are significant effected on improvement of learning outcomes.

The taken decision based on the value of significance as follows.

1. If the probability value $(\mathrm{p})>0.05, \mathrm{H}_{0}$ is accepted.

2. If the probability value $(\mathrm{p})<0.05, \mathrm{H}_{0}$ is rejected.

\section{RESULTS AND DISCUSSIONS}

Data of this study consisted of critical thinking skills criteria and gains score of student learning outcomes. The data obtained by the measurement results with test questions. the test used in this study consisted of 6 items essay, using the technique of scoring the ultimate answer is 4 .

The item test used to measure student learning outcomes has been validated. The item test is trialed on students in addition to the experimental class and control. The trial results showed that the item test is valid, reliable, good for the level of difficulty, and enough to distinguishing test. Thus, the item test is eligible used to measure learning outcomes.

\section{Students' Critical Thinking Skill}

The critical thinking skills criteria of experiment group consists of very critical, critical, quite critical enough, less critical, and uncritically. Descriptions of critical thinking skills criteria for experiments group using percentages. Percentage of critical thinking skills of students in the experimental group can be seen in table 2 below.

Table 1. Percentage of Critical Thinking Skills on Experiment Group

\begin{tabular}{cccc}
\hline \multirow{2}{*}{ No. } & \multirow{2}{*}{ Criteria } & \multicolumn{2}{c}{ Percentage } \\
\cline { 3 - 4 } & & Pretest & Posttest \\
\hline 1. & Very Critical & 0 & 76.67 \\
2. & Critical & 23.33 & 23.33 \\
3. & Quite Critical & 63.33 & 0 \\
4. & Less Critical & 13.33 & 0 \\
5. & Uncritically & 0 & 0 \\
Total & & 100 & 100 \\
\hline
\end{tabular}

The data of critical thinking skills and student learning outcomes are obtained by measuring the results with test. The descriptions of critical thinking skills criteria for experiment group are shown in percentages in figure 1 .

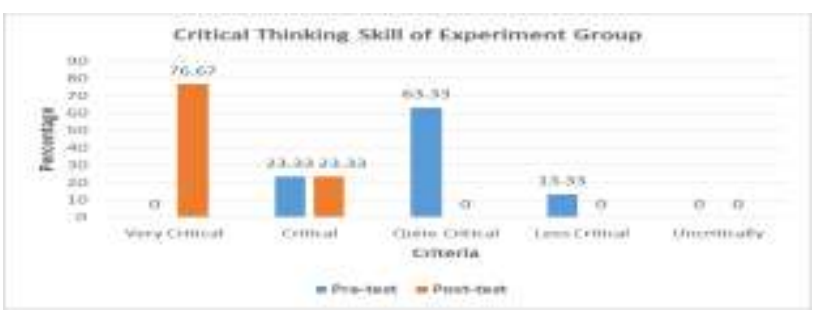

Figure 1: Critical Thinking Skills of Experiment Group

The picture above shows the difference in the percentage of critical thinking ability of experiment group between pre_test and Posttest. Criteria of critical thinking skills in the pre_test consists of critical 23.33\%; quite critical $63.33 \%$; and less critical $13.33 \%$. Criteria of critical thinking skills in the Posttest consists of a very critical $76.67 \%$ and critical $23.33 \%$.

Based on this data, that there is an increased on students' critical thinking skills of experiment group after learn with PBL model. It was identified from the data criteria 
to think very critically increased $76.67 \%$ after the posttest. The criteria of critical are a fixed percentage, $23: 33 \%$, while the criteria is quite critical and less critical there is $0 \%$. This suggests that increasing student' critical thinking skills.

The critical thinking skills criteria of control group consists of very critical, critical, quite critical enough, less critical, and uncritically. Descriptions of critical thinking skills criteria for control group using percentages. Percentage of critical thinking skills of students in the control group can be seen in table 3 below.

Table 2. Percentage of Critical Thinking Skills on Control Group

\begin{tabular}{cccc}
\hline \multirow{2}{*}{ No. } & \multirow{2}{*}{ Criteria } & \multicolumn{2}{c}{ Percentage } \\
\cline { 3 - 4 } & & Pretest & Posttest \\
\hline 1. & Very Critical & 0 & 10.34 \\
2. & Critical & 24.14 & 82.76 \\
3. & Quite Critical & 75.86 & 6.90 \\
4. & Less Critical & 0 & 0 \\
5. & Uncritically & 0 & 0 \\
Total & & $\mathbf{1 0 0}$ & $\mathbf{1 0 0}$ \\
\hline
\end{tabular}

The percentage of critical thinking skills of students in the control group can be seen in figure 2 .

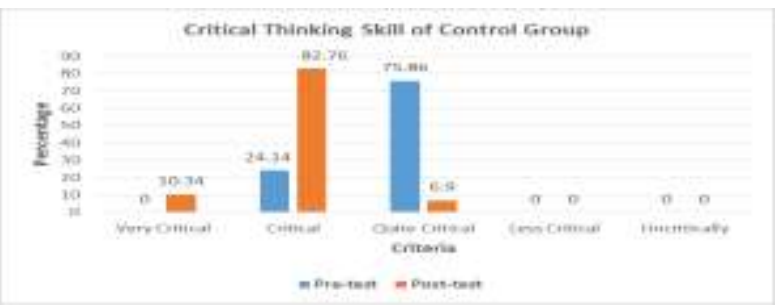

Figure 2: Critical Thinking Skills of Control Group

The picture above shows the differences in the percentage of critical thinking skills control group between pre_test and Posttest. Criteria of critical thinking skills in the pre_test consists of critical $24.14 \%$ and quite critical $75.86 \%$. Criteria of critical thinking skills in the Posttest consists of very critical $10.34 \%$; critical $82.76 \%$; and quite critical $6.90 \%$.

Based on this data, that there is an increased on students' critical thinking skills of control group after learn with lecture and discussion model. It was identified from the data criteria to think very critically increased $10.34 \%$ after the posttest. The criteria of critical are increasing, $58.62 \%$, while the criteria for quite critical is down, $68.96 \%$. This suggests that increasing students' critical thinking skills.

Based on the critical thinking skills data of the experimental group and control group, can be concluded that there are differences of critical thinking skills enhancement between experiment group and control group. The critical thinking skills enhancement of experiment group is higher than that of control group.

\section{Students' Learning Outcome}

The student learning outcomes data consists of the average score of pre_test, Posttest, and gain scores. Figure 3 shows the score of experiment group and control group learning outcomes.

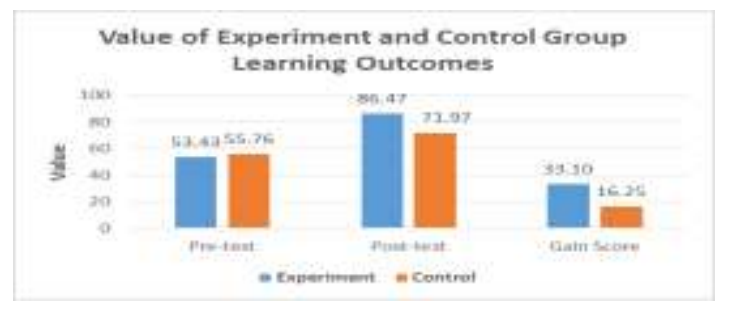

Figure 3: Value of Experiment and Control Group Learning Outcome

The value of Experiment and Control Group Learning Outcome data shows that learning outcomes of experimental group is lower, 2.33 than the control group during pretest. At the time of posttest, learning outcomes of experimental group is higher, 14.50 than the control group. Thus obtained value of gain scores of experimental group is higher, 16.85 than the control group.

The statistics of student learning outcome can be concluded that: (1) the average score of experiment group pretest is lower than that of the control group; (2) the average score of experiment group Posttest is higher than that of the control group; and (3) the average of experiment group gain score is higher than that of the control group. 
The analysis of PBL effect on learning outcomes using a independent sample t-test model. The t-test is a statistical parametric form, and then the learning outcomes data should be normally distributed and homogeneous. Before the data are analyzed, it is necessary to test the normality and homogeneity. The results of learning outcomes data normality test can be seen in table 4 below.

Table 3. The Results of Normality Test

\begin{tabular}{ccc}
\hline & & One-Sample Kolmogorov-Smirnov Test \\
\hline & $\mathrm{N}$ & Unstandardized Residual \\
Normal & Mean & 29 \\
Parameters $^{\mathrm{a}}$ & Std. Deviation & .0000000 \\
Most Extreme & Absolute & 12.82234810 \\
Differences & Positive & .163 \\
& Negative & .163 \\
Kolmogorov-Smirnov Z & -.086 \\
Asymp. Sig. (2-tailed) & .879 \\
a. Test distribution is Normal. & .422 \\
\hline
\end{tabular}

Based on the results of normality test, shows that the significant (two-tailed) $=0.422$ $>$ significant $=0.05$ (coefficient). So it can be concluded that the student learning outcomes data are normally distributed. The results of learning outcomes data homogeneity test can be seen in table 5 below.

Table 4. The Results of Homogeneity Test

\begin{tabular}{rrrrr}
\hline \multicolumn{4}{c}{ Test of Homogeneity of Variances } \\
\hline $\begin{array}{r}\text { Experiment } \\
\text { Levene Statistic }\end{array}$ & df1 & & df2 & Sig. \\
1.278 & & 5 & 21 & .310 \\
\hline
\end{tabular}

Based on the results of the homogeneity test, shows that significant $=$ $0.310>$ significant $=0.05$ (coefficient). So it can be concluded that the student learning outcomes data are homogeneous.

The gain score data of learning outcomes proved to be homogenous and normally distributed then tested using the ttest. The gain score data are analyzed to partially in order to know the significance of the difference in specific. The results of independent samples t-test can be seen in table 6 below.

Table 5. Value of Independent Samples t_test

Independent Samples Test

\begin{tabular}{|c|c|c|c|c|c|c|c|c|c|c|}
\hline \multirow[b]{4}{*}{$\begin{array}{l}\text { Gain } \\
\text { Score }\end{array}$} & & \multicolumn{4}{|c|}{$\begin{array}{c}\text { Levene's Test } \\
\text { for Equality } \\
\text { of Variances }\end{array}$} & \multicolumn{5}{|c|}{ t_test for Equality of Means } \\
\hline & & \multirow[b]{2}{*}{$\mathrm{F}$} & \multirow[b]{2}{*}{ Sig. } & \multirow[b]{2}{*}{$\mathrm{t}$} & \multirow[b]{2}{*}{ df } & \multirow{2}{*}{$\begin{array}{l}\text { Sig. (2- } \\
\text { tailed) }\end{array}$} & \multirow{2}{*}{$\begin{array}{c}\text { Mean } \\
\text { Difference }\end{array}$} & \multirow{2}{*}{$\begin{array}{l}\text { Std. Error } \\
\text { Difference }\end{array}$} & \multicolumn{2}{|c|}{$\begin{array}{l}\text { 95\% Confidence Interval of } \\
\text { the Difference }\end{array}$} \\
\hline & & & & & & & & & Lower & Upper \\
\hline & $\begin{array}{c}\text { Equal } \\
\text { variances } \\
\text { assumed }\end{array}$ & 8.668 & .005 & 6.164 & 57 & .000 & 16.859 & 2.735 & 11.382 & 22.336 \\
\hline & $\begin{array}{c}\text { Equal } \\
\text { variances not } \\
\text { assumed }\end{array}$ & & & 6.214 & 47.847 & .000 & 16.859 & 2.713 & 11.403 & 22.314 \\
\hline
\end{tabular}


The student learning outcomes are tested using independent sample t-test. The results show that there are significant differences of student learning outcomes between experiment group and control group. The evidence is from the results of the t test calculation is worth significant $(2$ tailed $)=$ $0.000<$ significant $=0.05$ (coefficient). Specifically, it can be concluded that the student learning outcomes of PBL is higher than that of lectures and group discussions model.

Based on the analysis of data from the research findings, the first, critical thinking skills of experiment group is higher than the control group. Second, the PBL model is significant to improve the student learning outcomes.

The results of this study indicate that there are differences in the ability of critical thinking between the experimental and control group. The critical thinking skills of experimental group are higher than the control group. PBL model selection in this study because it has advantages, improves the ability to think critically.

Empirically, the effect of PBL model on critical thinking skill is reinforced by Masek \& Yamin (2011) research, states that the specific processes in PBL theoretically support student' critical thinking development according to the design applied. The PBL strategies affected on critical thinking skill and student learning outcomes in Misouri junior high school (Burris \& Garton, 2007)

Further results of these studies have in common with the findings (Hadi, 2013) that the PBL strategies is effected on critical thinking skills and Biologys' learning outcomes in Malang public senior high school. In addition, the results of (Kurniawati, 2016) research also shows that the PBL model can improve students' critical thinking at sains on fourth grade in elementary school.

By using a model of PBL, the improvement of the critical thinking skills is higher because the students are more active during their learning in the classroom. Students are actively constructing their knowledge through discussion and questions based on the real problems. It can optimally encourage their critical thinking skills. PBL is able to manage the attitude of curiosity and the ability to think objectively, independently, critically and analytically both individually and in groups (Sumarni \& others, 2015).

According Ishaq (2008), there are four skills of critical thinking is problem solving), decision making, critical thinking, and creative thinking. It all boils down to highlevel thinking skills that include activities such as analysis, synthesis, and evaluation. Murti (2010) stated that critical thinking is different from thinking alone. Critical thinking is an intellectual thought process in which thinkers deliberately assess the quality of his thinking. Thinkers use reflective thinking, independent, clear, and rational. Critical thinking is the process of analyzing or evaluating information on a problem based on logical thinking to determine the decision (Jacobsen, Eggen, \& Kauchak, 2002).

PBL model develops a higher-level thinking/critical thinking and scientific thinking skills of the students (Tandogan \& Orhan, 2007). During the discussion, groups of students are able to solve population problems that occur around their neighborhood due to their hard effort. It develops their ability to think critically.

It is the same as Murti (2010) that describes the characteristics of critical thinking is as follows.

1. Critical thinking requires effort to analyze knowledge and make conclusions based on the information and support data.

2. Critical thinking requires the ability to predict, identify the alleged information, distinguish between facts, theories, opinions, and beliefs.

3. Critical thinking requires the ability to analyze of issues and find solutions to overcome these problems by collecting information and assessing knowledge and conclusions. 
4. Critical thinking is also associated with good language skills, able to interpret the data, assess the evidence and arguments, as well as be able to identify whether there is a logical relationship between the alleged one with the other allegations.

5. The critical thinking ability to draw conclusions and test conclusions, reconstruct the pattern of belief held by a broader experience, and perform accurate judgment about specific things in everyday life.

Not only critical thinking skill, but also the results of this study indicate that the PBL model significant effected on the results of learning outcome. This is consistent with the findings (Lestari, 2011) that the learning outcomes grade science students in SMPN 2 Blitar who learn by Problem Based Learning is higher than students who studied conventionally. The same research results delivered by (Wulandari \& Surjono, 2013) that there are significant differences in learning outcomes among students taught by PBL method with students taught by demonstration methods. Learning outcomes of students who are taught by PBL method is higher than the learning outcomes of students who are taught by the method of demonstration.

PBL model influences the student learning outcomes because: first, the PBL model is a problem-based learning. Second, PBL model teaches the students to solve the problems through group discussion.

PBL models can develop the students' thinking skills and knowledge. Thinking process is a series of skills such as collecting information or data, read something about the data, and others whose application takes practice and habituation. The students get used to solve the population problems that often occur in Indonesia, so that they get a higher study result than the students who only listen to their teacher's explanation.

The population problems presented in PBL trigger the students to find the alternative solutions. Therefore, the learning outcome of experiment group is higher than that of control group. Barrows explains that PBL which discusses the issues can challenge the students to solve problems with their knowledge. Moreover, Amir (2009) explains that the closer the problem to the real world, the better the effect in improving the efficiency of the learners. The statement is relevant to this study since the learning materials focus on the population problems in society.

Through PBL models students can learn to solve their problems through group discussion. It can be seen on the stages of research and investigation group that trains students to exchange ideas when solving problems. PBL models makes them do more discussion and question and answer to enhance their understanding (Koestiningsih, 2011). The idea contribution of other members of the group increases students' knowledge. Thus, it will increase their learning outcomes.

The implementation of learning in the classroom, found several weaknesses in this study, including the allocation of time in the troubleshooting process is still lacking. Students cannot manage time in every stage of PBL. This is because the students are still not ready to accept the subject matter. Some students do not focus on completing the work group, so that the time given teachers are not used to the maximum. Thus, learning objectives can be achieved with the maximum, then the added time at each stage of PBL.

The students' interest in learning to follow is still low. Some students are lazy and crowded became an obstacle in the implementation of learning. Students who are lazy are "reluctant" to help the group in completing its tasks. A contribution to the discussion group is dominated by the diligent student.

The weaknesses of PBL same with the opinion of Tandogan \& Orhan (2007) that the Problem Based Learning has some weaknesses in its application, is as follows. 
(1) It could be difficult for teachers to change their teaching styles. (2) It could take more time for students to solve problematic situations when these situations are firstly presented in the class. (3) Groups or individuals may finish their works earlier or later. (4) Problem-based learning requires rich material and research. (5) It is difficult to implement problem-based learning model in all classes. (6) It is unfruitful to use this strategy with students who could not fully understand the value or scope of the problems with social content. (7) It is quiet difficult to assess learning.

PBL weaknesses among others present in the aspect: the student's interest and time effectiveness. Students who are less interested in going to interfere with learning, because changing learning habits of students who are teacher centered to student centered is its own difficulties for students. For the first class to apply, this model require a lot of time in the process of solving problems.

For students who are interested in participating in learning PBL, it is given a gift in the form of snack and adding value to students who are active in express opinions, argue, and help provide an answer during the learning takes place.

\section{CONCLUSION AND RECOMMENDATION}

The conclusion of this study shows that the problem based learning model affects the students' critical thinking skills and learning outcomes in SMA Negeri 6 Malang. The critical thinking skills and learning outcomes of experiment group is higher than that of the control group.

Based on the conclusion, the authors suggests: first, geography teachers should familiarize their students to think critically to solve authentic problems. Second, other researcher who conducts further similar study should extend the time allocation at each stage of PBL and develop a conductive atmosphere in the classroom to prepare the students' learning with PBL.

\section{REFERENCES}

Amir, M. T. (2009). Inovasi pendidikan melalui problem based learning. Jakarta: Kencana Prenada Media Group.

Anwar, C. (2017). The Effectiveness of problem based learning integrated with Islamic values based on ICT on higher order thinking skill and students' character. Al-Ta Lim Journal, 23(3), 224-231.

Barrows, H. S. (1996). Problem-based learning in medicine and beyond: A brief overview. New Directions for Teaching and Learning, 1996(68), 312.

Burris, S., \& Garton, B. L. (2007). Effect of Instructional Strategy on Critical Thinking and Content Knowledge: Using Problem-Based Learning in the Secondary Classroom. Journal of Agricultural Education, 48(1), 106116.

De Graaf, E., \& Kolmos, A. (2003). Characteristics of problem-based learning. International Journal of Engineering Education, 19(5), 657662.

Dochy, F., Segers, M., Van den Bossche, P., \& Gijbels, D. (2003). Effects of problem-based learning: A metaanalysis. Learning and Instruction, 13(5), 533-568.

Gunantara, G., Suarjana, I. M., \& Riastini, P. N. (2014). Penerapan Model Pembelajaran Problem Based Learning untuk Meningkatkan Kemampuan Pemecahan Masalah Matematika Siswa Kelas V. MIMBAR PGSD, 2(1).

Hadi, A. (2013). Pengaruh pembelajaran problem based learning (PBL) terhadap kemampuan berpikir kritis dan pemahaman konsep biologi siswa SMA Negeri di kota Malang. SKRIPSI Jurusan Biologi-Fakultas MIPA UM. 
Hmelo-Silver, C. E. (2004). Problem-based learning: What and how do students learn? Educational Psychology Review, 16(3), 235-266.

Ishaq, I. (2008). Model-model pembelajaran mutakhir: perpaduan IndonesiaMalaysia. Pustaka Pelajar.

Jacobsen, D. A., Eggen, P. D., \& Kauchak, D. P. (2002). Methods for teaching: Promoting student learning. Prentice Hall.

Koestiningsih, N. (2011). Perbedaan Hasil Belajar Siswa Yang Belajar Dengan Menggunakan Strategi Problem Based Learning (PBL) dan Konvensional Siswa Kelas $X$ di SMKN 1 Blitar.(Tesis). Disertasi Dan Tesis Program Pascasarjana UM.

Kronberg, J. R., \& Griffin, M. S. (2000). Analysis problems-A means to develop students' critical-thinking skills. Journal of College Science Teaching, 29(5), 348.

Kurniawati, K. (2016). Pengaruh Model Project Based Learning (PjBL) Dan Problem Based Learning (PBL) Terhadap Kemampuan Berfikir Kreatif Siswa. Universitas Terbuka.

Lestari, D. (2011). Pengaruh Model Pembelajaran Problem Based Learning terhadap Hasil Belajar IPA Siswa Kelas VIII SMPN 2 Blitar Ditinjau dari Kemampuan Dasar Matematika.(Tesis). DISERTASI Dan TESIS Program Pascasarjana UM.

Masek, A., \& Yamin, S. (2011). The effect of problem based learning on critical thinking ability: a theoretical and empirical review. International Review of Social Sciences and Humanities, 2(1), 215-221.

Mills, J. E., Treagust, D. F., \& others. (2003). Engineering education-Is problembased or project-based learning the answer. Australasian Journal of Engineering Education, 3(2), 2-16.

Muhson, A. (2009). Peningkatan Minat Belajar dan Pemahaman Mahasiswa Melalui Penerapan Problem-Based Learning. Jurnal Kependidikan, 39(2).

Murti, B. (2010). Berpikir Kritis (Critical Thinking). Jurnal Kedokteran, 6(1), $1-5$.

Paloloang, M. F. B. (2014). Penerapan model problem based learning (PBL) untuk meningkatkan hasil belajar siswa pada materi panjang garis singgung persekutuan dua lingkaran di kelas VIII SMP Negeri 19 Palu. Jurnal Elektronik Pendidikan Matematika Tadulako, 2(1).

Romauli, T., Rahayu, G. R., Suhoyo, Y., Dibyasakti, B. A., \& Mustikarachmi, V. S. (2009). Pengembangan indikatorindikator tingkat pelaksanaan PBL berdasarkan pembelajaran konstruktif, mandiri, kolaboratif dan kontekstual. Jurnal Pendidikan Kedokteran Dan Profesi Kesehatan Indonesia, 4(1), 46-57.

Rusnayati, H., \& Prima, E. C. (2011). Penerapan model pembelajaran problem based learning dengan pendekatan inkuiri untuk meningkatkan keterampilan proses sains dan penguasaan konsep elastisitas pada siswa SMA. In Prosiding Seminar Nasional Penelitian, Pendidikan Dan Penerapan MIPA, Fakultas MIPA, Universitas Negeri Yogyakarta.

Sadia, I. W. (2007). Pengembangan Kemampuan Berpikir Formal Siswa SMA Melalui Penerapan Model Pembelajaran Problem Based Learning dan Cycle Learning dalam Pembelajaran Fisika. Jurnal Pendidikan Dan Pengajaran UNDIKSHA, 1-20. 
Savery, J. R. (2015). Overview of problembased learning: Definitions and distinctions. Essential Readings in Problem-Based Learning: Exploring and Extending the Legacy of Howard S. Barrows, 9, 5-15.

Savery, J. R., \& Duffy, T. M. (1995). Problem based learning: An instructional model and its constructivist framework. Educational Technology, 35(5), 3138.

Savin-Baden, M., \& Major, C. H. (2004). Foundations of problem-based learning. McGraw-Hill Education (UK).

Setyorini, U., Sukiswo, S. E., \& Subali, B. (2011). Penerapan model problem based learning untuk meningkatkan kemampuan berpikir kritis siswa SMP. Jurnal Pendidikan Fisika Indonesia, $7(1)$.

Srinivasan, M., Wilkes, M., Stevenson, F., Nguyen, T., \& Slavin, S. (2007).
Comparing problem-based learning with case-based learning: effects of a major curricular shift at two institutions. Academic Medicine, 82(1), 74-82.

Suci, N. M. (2008). Penerapan Model Problem Based Learning untuk meningkatkan partisipasi belajar dan hasil belajar teori akuntansi mahasiswa jurusan ekonomi Undiksha. Jurnal Penelitian Dan Pengembangan Pendidikan, 2(1), 7486.

Tandogan, R. O., \& Orhan, A. (2007). The Effects of Problem-Based Active Learning in Science Education on Students' Academic Achievement, Attitude and Concept Learning. Online Submission, 3(1), 71-81.

Wulandari, B., \& Surjono, H. D. (2013). Pengaruh problem-based learning terhadap hasil belajar ditinjau dari motivasi belajar PLC di SMK. Jurnal Pendidikan Vokasi, 3(2). 